\title{
SUMBANGAN TUN ABDUL RAZAK DALAM MEMBINA HUBUNGAN MALAYSIA-INDONESIA
}

\author{
Mohd Sohaimi Esa
}

\begin{abstract}
Tun Abdul Razak (1922-1976) was the second Prime Minister of Malaysia and was popularly known as "The Father of Development". He is also among the leading fegures in the country who helped to enhance Malaysia's relations with Indonesia. It is clear that as a neighbour to Indonesia, the historical ties and comman ethnic and cultural linkages assisted considerably in the strengthening bilateral relations. Tun Abdul Razak recognised Malaysia's special relationship with Indonesia compared to others countries. This article examines Tun Razak's role and contribution in building formal relations between the two countries. In addition to bilateral relations, this article will also discuss several issues that arose at the time especially during the confrontation which Tun Razak had to handle. This article will show that Tun Razak played an influential role and diplomatically during and after confrontation. He was directly involved in many of the negotians. As Deputy Prime Ministar he was a key leader who turned around the deteriorating relations.
\end{abstract}

\section{Pengenalan}

Tanggal 31 Ogos 1957, bukan sahaja penting dalam konteks kemerdekaan, tetapi juga dapat dilihat sebagai suatu dimensi baru dalam hubungan Malaysia dengan Indonesia yang sejak sekian lama dijajah oleh kuasa Barat. Sebagai negara yang berjiran, faktor pertalian sejarah, rumpun bangsa, dan kebudayaan yang rapat menjadikan hubungan ini sebagai sesuatu yang istimewa apatah lagi sejak sekian 
lama dibelenggu penjajahan. Bagi Tun Abdul Razak, beliau telah menyedari tentang keistimewaan dalam hubungan Malaysia-Indonesia berbanding dengan negara-negara lain. Justeru itu, artikel ini berusaha untuk melihat peranan dan sumbangan Tun Abdul Razak dalam membina hubungan secara rasmi di antara kedua-dua kerajaan. Selain kerjasama dua hala, perbincangan turut menyentuh beberapa isu semasa yang perlu ditangani oleh Tun Abdul Razak, khususnya semasa era konfrontasi Malaysia-Indonesia.

\section{Penglibatan Awal Tun Abdul Razak Dalam Arena Politik}

Tun Abdul Razak (1922-1976) merupakan Perdana Menteri Malaysia kedua yang lebih dikenali sebagai "Bapa Pembangunan Negara." Beliau memulakan kariernya di negeri Pahang dengan menjawat jawatan sebagai Setiausaha Kerajaan Negeri dan kemudiannya dilantik sebagai Menteri Besar. Pada masa yang sama, Tun Abdul Razak terlibat secara aktif dalam politik dengan menjadi pemimpin tertinggi UMNO. Dalam UMNO, beliau dipilih sebagai Ketua Pemuda dan kemudiannya Timbalan Yang Dipertua. Gandingan serasi Tunku Abdul Rahman-Tun Abdul Razak terus kekal untuk tempoh yang panjang dalam pesada politik tanah air. Sementara itu, Tun Abdul Razak adalah antara tokoh utama dalam memperjuangkan kemerdekaan tanah air.

Selepas merdeka, Tun Abdul Razak dilantik sebagai Timbalan Perdana Menteri merangkap beberapa kementerian iaitu Menteri Pertahanan, Menteri Pembangunan Luar Bandar dan Menteri Hal Ehwal Dalam Negeri. Malahan beliau turut memainkan peranan utama dalam beberapa peristiwa penting negara seperti penubuhan Malaysia, konfrontasi Malaysia-Indonesia, penyingkiran Singapura 1965 dan tragedi 13 Mei 1969. Selepas tragedi 13 Mei, Tun Abdul Razak berada dikemuncak dalam karier politiknya apabila dilantik sebagai Perdana Menteri Malaysia kedua. Sebagai Perdana Menteri, jasanya sentiasa dikenang kerana mengasaskan Dasar Ekonomi Baru (DEB), Barisan Nasional dan mempelopori dasar luar negara yang lebih dinamik dan terbuka. Dalam konteks dasar luar negara, beliau antara tokoh yang turut memainkan peranan penting dalam usaha mengukuhkan hubungan Malaysia-Indonesia. Tambahan pula, beliau berketurunan Bugis Sulawesi yang juga menunjukkan pertalian yang sangat rapat antara dirinya dengan Indonesia. ${ }^{1}$ 
Gambar 1

Tun Razak sewaktu menerima hadiah kapal layar "Putera Makasar" dari Gabenor Sulawesi Selatan di Pelabuhan Kelang, Selangor pada 1 September 1975.

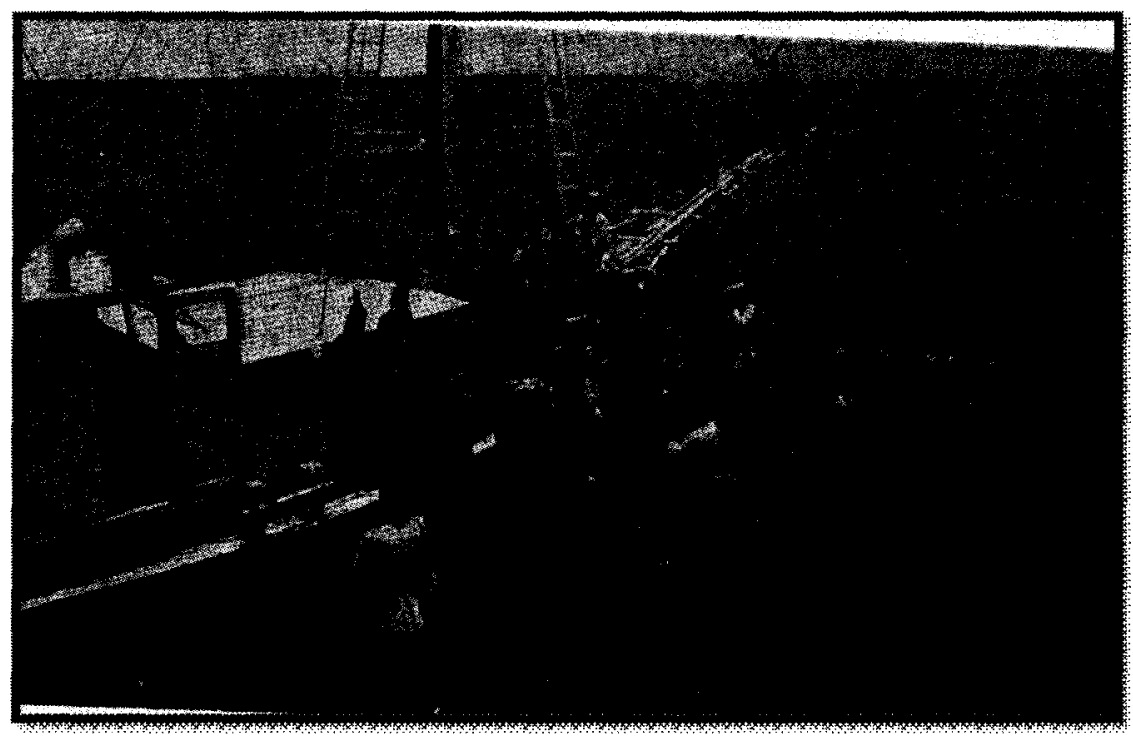

Sumber : Ucapan-ucapan Tun Haji Abdul Razak Bin Hussein 1975, Arkib Negara Malaysia dan Jabatan Perdana Menteri, Kuala Lumpur, 1977.

Sebaik sahaja kemerdekaan disambut, Tun Abdul Razak telah dilantik sebagai Timbalan Perdana Menteri Persekutuan Tanah Melayu. Di Tanah Melayu, Tunku Abdul Rahman-Tun Abdul Razak merupakan gandingan yang serasi dalam sejarah politik negara ini sepertimana Sukarno-Hatta di Indonesia. Semasa sambutan kemerdekaan, Tun Abdul Razak selaku Pengerusi Jawatankuasa Pusat Merdeka peringkat negara turut tidak ketinggalan menjemput wakil kerajaan Indonesia untuk hadir dalam majlis meraikan hari bersejarah tersebut di Stadium Merdeka pada 31 Ogos 1957. 2 Kemerdekaan Tanah Melayu itu disambut baik oleh Indonesia yang telah pun bebas dari penjajahan sejak 1945 lagi.

Dr. Subandrio, Menteri Luar Indonesia yang datang ke Kuala Lumpur untuk merayakan kemerdekaan Tanah Melayu menyatakan, “kebebasan Tanah Melayu akan membuka satu babak baru dalam hubungan Tanah Melayu-Indonesia". ${ }^{3}$ Indonesia juga menegaskan bahawa sokongan akan diberikan kepada Malaysia untuk masuk ke PBB. Tun Abdul Razak juga mengalu-alukan kerjasama itu sama ada 
dalam bidang sosial, kebudayaan dan ekonomi yang dibentuk melalui persetujuan dan pertukaran lawatan pemimpin kedua-dua negara.

\section{Lawatan Rasmi Tun Abdul Razak ke Indonesia}

Pada 19 November 1958, Tun Abdul Razak selaku Timbalan Perdana Menteri merangkap Menteri Pertahanan telah memulakan kerjasama dengan mengetuai satu rombongan muhibah ke Indonesia. ${ }^{4}$ Rombongan Tun Abdul Razak terdiri daripada Cheah Owe Keat (Federal Legislative Caunselor), Mohd. Ghazali Shafie (Timbalan Setiausaha Tetap Kementerian Luar Negeri), Syed Nasir Ismail (Pengarah Dewan Bahasa dan Pustaka) dan Mohd. Khir Johari (Menteri Pelajaran). Selama seminggu, rombongan Tun Abdul Razak itu telah mendapat sambutan baik dan liputan meluas dari media di Indonesia. Menteri Penerangan Indonesia, Ruslan Abdul Chani menegaskan bahawa hubungan kedua-dua negara masih baik sungguhpun terdapat beberapa masalah dalam politik: ${ }^{5}$

The two countries are inseparable, only political development keeping them apart. In the field of friendship, however, no force can separate them since both hold to the idea of freedom and independence. ${ }^{6}$

Sekiranya Indonesia memberi penekanan kepada persamaan ideologi sebagai asas persahabatan mereka, Malaysia pula melihat keakraban hubungan kepada jalinan sejarah dan persaudaraan yang terdapat di antara kedua-dua negara itu sepertimana yang ditegaskan dalam ucapan balas Tun Abdul Razak:

Malaya is looking to Indonesia as an example and inspiration in order to be able to bring a common welfare and a common security to both. Relations which have existed for so long between Indonesia and Malaya should enable them to make joint efforts on the international plans in their mutual interest.?

Sememangnya tidak dapat dinafikan Tanah Melayu yang baru sahaja merdeka melihat ke arah Indonesia dari segi kepimpinan intelektual, politik dan kebudayaan. Hubungan yang erat dari segi sosial dan kebudayaan itu merupakan lanjutan daripada hubungan sejarah yang telah berlaku sejak sekian lama.

Semasa di Indonesia, Tun Abdul Razak dan rombongan telah dibawa melawat Akademi Tentera Kebangsaan Indonesia di Magelang dan Akademi Tentera Laut di Surabaya. Pada 27 November, lawatan tersebut berakhir dengan Tun Abdul Razak dan Naib Perdana Menteri 
Indonesia, Hardi telah mengeluarkan kenyataan bersama iaitu untuk merapatkan lagi hubungan dan kerjasama Persekutuan Tanah MelayuIndonesia. Kerjasama ini merangkumi hubungan diplomatik, kebudayaan, bahasa dan keselamatan. ${ }^{8}$

Dari segi keselamatan, Tun Abdul Razak turut berjanji bahawa Tanah Melayu akan bekerjasama dengan kerajaan Indonesia untuk menyekat kemasukan pemberontakan PRRI (Pemerintah Revolusioner Republik Indonesia) ke Tanah Melayu. Beliau mencadangkan agar kerajaan Indonesia memberi senarai nama pemberontak dan membatalkan dokumen perjalanan mereka. Dengan langkah ini, maka kerajaan Tanah Melayu akan dapat menyekat atau menamatkan pemberian suaka politik ke atas pemberontak tersebut. Cadangan Tun Abdul Razak itu disambut baik oleh kerajaan Indonesia. ${ }^{9}$ Jelas, cadangan Tun Abdul Razak itu adalah antara langkah terbaik untuk mengekalkan persahabatan di antara kedua-dua negara.

Usaha ke arah memupuk perasaan muhibah tersebut diteruskan lagi dengan lawatan balas pihak Indonesia yang diketuai oleh rakan sejawatan dengan Tun Abdul Razak, iaitu Timbalan Presiden, Dr. Djuanda ke Tanah Melayu pada bulan April 1959. Satu perjanjian persahabatan ditandatangani pada 17 April 1959, iaitu yang pertama yang dibuat antara kedua-dua negara sejak Tanah Melayu mencapai kemerdekaan. Dr. Djuanda menganggap perjanjian ini sebagai simbol hubungan persaudaraan yang bertepatan dengan hasrat Tanah Melayu sepertimana yang dinyatakan oleh Ghazali Shafie sebagai, "extremely significant" yang memperlihatkan "an affirmation of the renewal of historical, racial and cultural ties." ${ }^{10}$ Walau bagaimanapun, hubungan ini tidak dapat bertahan lama akibat tercetusnya konfrontasi MalaysiaIndonesia yang perlu ditangani secara bijaksana oleh pemimpin negara, termasuklah Tun Abdul Razak.

\section{Menangani Isu Konfrontasi Malaysia-Indonesia}

Malaysia yang mengandungi Persekutuan Tanah Melayu, Singapura, Sabah dan Sarawak telah diisytiharkan pada 16 September 1963. Serentak itu juga Indonesia dan Filipina tidak mahu memberikan pengiktirafan diplomatik ke atas negara baru itu dan kedua-dua negara berkenaan telah memutuskan hubungan dengan Persekutuan Tanah Melayu. Kerajaan Filipina terus menentang penubuhan Malaysia apabila menuntut Sabah sebahagian dari wilayahnya. Sementara perbalahan di antara Indonesia dengan Malaysia juga terus berpanjangan sejak 13 Februari 1962 apabila Presiden Sukarno mengisytiharkan Malaysia sebagai projek neokolonialisme yang mesti diganyang. ${ }^{11}$ Keadaan ini memberi tamparan hebat kepada para 
pemimpin Malaysia, termasuk Tun Abdul Razak untuk menangani masalah konfrontasi tersebut.

Presiden Sukarno mendakwa pengumuman tarikh penubuhan Malaysia adalah bertentangan dengan "Manila Accord". Malaysia sepatutnya dibentuk selepas PBB menyiasat kehendak penduduk Sabah dan Sarawak. ${ }^{12}$ Selaku Timbalan Perdana Menteri, Tun Abdul Razak terpaksa mengulas dakwaan itu dengan menjelaskan bahawa Malaysia wujud selepas kerajaan-kerajaan yang terlibat, yakni Singapura, Sabah dan Sarawak mengesahkan Perjanjian Malaysia. Malah, Setiausaha Agung PBB atau wakilnya telah diberi tempoh yang mencukupi untuk meninjau pendapat penduduk Sabah dan Sarawak sepertimana yang dipersetujui dalam "Manila Accord". ${ }^{13}$ Tun Abdul Razak turut menegaskan bahawa:

We have no territorial ambitions, the joining together of Sabah, Sarawak and Singapore with former Malaya to form Malaysia was not an act of self aggrandisment; it was a fact of Democracy. It was the joining together of free people with free will, a decision by the people themselves implemented by their own leaders who were chosen by a truely democratic process. ${ }^{14}$

Tun Abdul Razak juga mengulas isu tersebut sepertimana berikut:

\begin{abstract}
Presiden Soekarno dan pembesar-pembesar Indonesia mengatakan bahawa Malaysia ini mengancam akan keselamatan dan kedudukan Indonesia. Tuduhan ini juga tidak dapat diterima ... kerana bagaimanakah sebuah negara yang mempunyai rakyat sepuluh juta ramainya boleh mengancam dan merupakan suatu bahaya kepada negara yang lebih besar seperti Indonesia, yang mempunyai rakyat seramai satu ratus juta orang, iaitu sepuluh kali ganda banyaknya daripada rakyat Malaysia. Tentulah sekali perkara ini mustahil..$^{15}$
\end{abstract}

Tun Abdul Razak menganggap bahawa dalang di sebalik penentangan Indonesia ke atas penubuhan Malaysia "adalah datangnya daripada Parti Komunis Indonesia."16 Sungguhpun begitu, Tun Abdul Razak masih mengharapkan tuduhan yang dilemparkan itu akan dapat diselesaikan dalam persidangan kemuncak di antara kedua-dua negara. Natijahnya, Malaysia dan Indonesia mempunyai persepsi dan pendapat yang berbeza mengenai ancaman komunis di Asia Tenggara. Bagi Indonesia, faktor utama yang mengancam keselamatan dan kestabilan rantau ini adalah kehadiran yang berterusan kolonialisme dan imperialisme lebih daripada komunisme. Malaysia pula berpandangan ancaman utama datang daripada pengaruh komunis. 
Sikap kedua-dua negara mengenai keserantauan juga berbeza apabila usaha Malaysia untuk memupuk persefahaman dan kerjasama serantau ditolak oleh Indonesia. Indonesia menganggap pertubuhan serantau sebagai lanjutan wawasan kolonialisme. Sikap inilah yang pernah mendasari penolakan Indonesia terhadap jemputan negara ini dalam ASA pada tahun $1961 .{ }^{17}$

Walau bagaimanapun, Indonesia terus melancarkan konfrontasi secara agresif dengan memutuskan segala hubungan dengan Malaysia, termasuk dari segi diplomatik, ekonomi, sosial dan komunikasi serta ancaman ketenteraan dan pencerobohan ke atas negara ini. Tun Abdul Razak menganggap Indonesia menjadi ancaman besar kepada keselamatan dan pertahanan Malaysia. Semasa sidang parlimen pada 23 Disember 1963, Tun Abdul Razak selaku Menteri Pertahanan telah menyeru rakyat Malaysia, khususnya di Sabah dan Sarawak supaya bersedia untuk mempertahankan tanah air daripada pencerobohan dan serangan pihak Indonesia. Beliau dengan nada tegas mengingatkan bahawa:

\begin{abstract}
We want to live in peace, but so long as our neighbours show that they have aggresive intentions againsts us or if they do not want to live in peace then we must take all possible measures to defend ourselves. We have taken steps to register people for national service and we have also taken steps to expand our territorial army by about 22,000 more men, exluding Singapore and the Borneo territories. ${ }^{18}$
\end{abstract}

Namun begitu, peristiwa pencerobohan tentera Indonesia di daerah Kalabakan, Sabah pada 29 Disember telah menguatkan lagi azam Tun Abdul Razak untuk mengambil langkah bersepadu bagi mempertingkatkan pertahanan dan keselamatan negara. ${ }^{19}$

Selain aspek pertahanan, Tun Abdul Razak bersama-sama dengan Tunku Abdul Rahman turut mengambil langkah diplomatik untuk menyelesaikan masalah konfontasi tersebut. Pada awal bulan Februari 1964, Tun Abdul Razak dipilih sebagai wakil Malaysia dalam Persidangan Peringkat Menteri di Bangkok. Dalam persidangan ini, Indonesia diwakili oleh Dr. Subandrio dan Filipina pula Setiausaha Luarnya, Salvador P. Lopez. Mesyuarat tiga penjuru itu dipengerusikan oleh Thanat Khoman, Menteri Luar Thailand. Pada mulanya, Malaysia enggan untuk menyertai rundingan ini kerana tidak yakin dengan keikhlasan Indonesia untuk menyelesaikan masalah konfrontasi tersebut. Namun begitu, desakan daripada Robert Kennedy ${ }^{20}$ dan jaminan yang diberikan oleh Thanat Koman bahawa Sukarno dan Macapagal mahukan keamanan mendorong Tun Abdul Razak untuk menyertai rundingan tersebut. ${ }^{21}$ 
Dalam persidangan pusingan pertama, agenda yang dibincangkan adalah berkaitan dengan gencatan senjata dan pengunduran tentera. Bagi Tun Abdul Razak, pengunduran tentera perlu diselesaikan terlebih dahulu sebelum dilaksanakan penyelesaian politik. Sebaliknya, Dr. Subandrio berpendapat penyelesaian politik perlu dilakukan sebelum dilaksanakan pengunduran tentera dan genjatan senjata. Dengan keputusan itu, Tun Abdul Razak berpendapat bahawa mereka tidak lagi perlu meneruskan rundingan selagi tentera Indonesia tidak berundur dari wilayah Malaysia. Agenda ini berakhir tanpa sebarang penyelesaian yang tuntas. Walau bagaimanapun, satu kenyataan bersama telah dikeluarkan oleh ketiga-tiga perwakilan, iaitu Perkara 6, mereka mengalu-alukan gencatan senjata di Sabah dan Sarawak sebagai langkah mewujudkan suasana yang baik bagi musyawarah MAPHILINDO. Mereka juga bersetuju menjemput Setiausaha Agung PBB untuk melantik Thailand sebagai negara yang bertanggungjawab mengawasi gencatan senjata tersebut. ${ }^{22}$

Salvador P. Lopez kemudiannya membangkitkan soal pangkalan tentera asing di Malaysia. Mesyuarat kemudiannya bersetuju untuk meminta Tun Abdul Razak mengeluarkan satu kenyataan bahawa pangkalan tentera British di Malaysia bukan bertujuan untuk mengancam Indonesia. Pada akhir mesyuarat, ketiga-tiga perwakilan bersetuju untuk mengadakan rundingan dengan kerajaan masingmasing bagi membolehkan satu lagi mesyuarat peringkat menteri sebelum diadakan Persidangan Kemuncak di Tokyo. ${ }^{23}$

Selepas persidangan pusingan pertama di Bangkok, Tun Abdul Razak atas arahan Tunku Abdul Rahman mengingatkan bahawa Malaysia akan terus menghalang pencerobohan tentera Indonesia. Tun Abdul Razak berpendapat bahawa persidangan di Bangkok merupakan satu perubahan yang menggalakkan ke arah mencari penyelesaian. ${ }^{24}$ Bagi Dr. Subandrio pula, walaupun ada kemajuan tetapi persetujuan itu adalah sangat rapuh. ${ }^{25}$

Sementara itu, Tun Abdul Razak telah mengutus surat untuk memohon bantuan daripada kerajaan British dalam usaha menangani masalah pencerobohan pesawat Indonesia ke ruang udara Malaysia. Surat yang diutuskan pada 21 Februari 1964, antara lainnya berbunyi:

The character of the danger is such that on behalf of the Malaysian Government I am constrained to seek the assistance of the British Government in accordance with the mutual defence agreement so that all measures would be taken to prevent any intrusions in particular those in violation of Malaysia airspace. Should there be a failure to take adequate measures at this stage to intercept any illegal flights over Malaysian territory I fear that it might result in 
grave doubts being entertained as to the value and effectiveness of the usual defence agreement with the British Government who alone is in a position to prevent aerial intrusion. ${ }^{26}$

Pada dasarnya, pesawat ini digunakan untuk menghantar bekalan makanan dan menggugurkan risalah kepada anggota tentera Indonesia yang masih berada dalam wilayah Malaysia. Surat Tun Abdul Razak itu telah dikemukakan oleh Duta Malaysia, Tunku Yaacob kepada Setiausaha Komanwel dan Menteri Pertahanan British. ${ }^{27}$

Sungguhpun Indonesia meneruskan usaha pencerobohan ke atas wilayah Malaysia di Sabah dan Sarawak pada 22 Februari 1964, tetapi tidak menghalang Malaysia untuk menghadiri persidangan peringkat kedua di Bangkok. Pada 2 Mac, Tun Abdul Razak sekali lagi dipilih untuk menyertai rundingan ini sebagai lanjutan yang diadakan sebelum ini. Rundingan ini dianggap ringkas dan isu pengunduran tentera masih merupakan agenda penting untuk Malaysia. Dalam rundingan tersebut, Dr. Subandrio mengulangi pendiriannya supaya langkah pengunduran dilakukan seiring dengan kemajuan penyelesaian dari segi politik. Cadangannya itu ditolak oleh Tun Abdul Razak. Tun Abdul Razak juga menolak cadangan Thailand dan Filipina supaya pengunduran dibuat secara berperingkat-peringkat. ${ }^{28}$

Tun Abdul Razak akhirnya bersetuju dengan cadangan Lopez yang mengutarakan beberapa perkara. Pertama, pengunduran tentera ke wilayah masing-masing, kedua, rundingan ke arah penyelesaian politik dilakukan pada masa yang sama dan ketiga, sidang kemuncak diadakan antara Tunku Abdul Rahman, Soekarno dan Macapagal sebaik sahaja pengunduran dilakukan sepenuhnya. ${ }^{29} \mathrm{~W}$ alau bagaimanapun, rundingan ini gagal apabila Indonesia tidak bersetuju dengan cadangan Lopez tersebut. Oleh itu, persidangan tiga penjuru di Bangkok tidak dapat menyelesaikan konflik di antara kedua-dua negara.

Pendirian tegas Tun Abdul Razak dalam rundingan itu telah mendapat pujian daripada kerajaan British. Dalam suratnya kepada Tunku Abdul Rahman, Perdana Menteri British menulis:

I was very glad to see that, in the negotiations at Bangkok, you stood firm on the need for the withdrawal from Malaysian territory of Indonesian regular and irregulars forces. You and Razak have shown great patience in pursuing these negotiations even beyond the point when a breakdown seemed certain. I am sure that as a result your potition in the eyes of the world is a strong one and can effectively be turned to Malaysian advantage. ${ }^{30}$

Pada 8 April 1964, Tun Abdul Razak mengadakan rundingan dengan Lord Carrington, Lord Head dan Major-Jeneral Wyldebore-Smith 
untuk membincangkan langkah menyekat pencerobohan tentera Indonesia. Mereka membincangkan cadangan Jeneral Walter Walker, supaya pasukannya dibenarkan merentasi sempadan Indonesia sejauh 3,000 ela. Tun Abdul Razak menyokong cadangan Jeneral Walter Walker kerana akan menjejaskan keupayaan Indonesia untuk menceroboh wilayah Malaysia. Dalam mesyuarat ini, Tun Abdul Razak juga bersetuju supaya Malaysia mengadu kepada Majlis Keselamatan PBB memandangkan tentera Indonesia masih lagi berada dalam wilayah Malaysia, walaupun telah diisytiharkan gencatan senjata. Beliau akan mengemukakan cadangan itu kepada kabinet untuk mendapatkan keputusan muktamad. ${ }^{31}$

Pada 12 Jun 1964, Tun Abdul Razak dan rombongannya telah berangkat ke Tokyo untuk menghadiri Sidang Kemuncak Persidangan Peringkat Menteri-Menteri Luar di Tokyo pada 20 Jun dan diikuti sehari kemudiannya Persidangan Ketua-ketua Negara. Semasa Persidangan Peringkat Menteri-Menteri Luar, persetujuan telah dicapai secara prinsipnya untuk menimbangkan cadangan Macapagal bagi menubuhkan Suruhanjaya Damai Afro-Asia. Suruhanjaya ini bertujuan untuk mengkaji dan mengemukakan syor penyelesaian konfrontasi Malaysia-Indonesia. Malaysia dan Indonesia semasa mesyuarat ini juga bersetuju untuk menerima cadangan Thailand tentang pembukaan pusat pemeriksaan di sempadan Sarawak-Kalimantan dan di sempadan Sabah-Kalimantan. ${ }^{32}$ Namun begitu, mesyuarat gagal mencapai kata sepakat apabila Indonesia enggan mengundurkan tenteranya dalam tempoh empat minggu dari wilayah Malaysia dan dihentikan sertamerta konfrontasi. ${ }^{33}$

Susulan kegagalan persidangan di Tokyo pada 24 Jun 1964, Tun Abdul Razak telah mengadakan perbincangan dengan Pesuruhjaya Tinggi United Kingdom, New Zealand dan Australia tentang ancaman Indonesia terhadap Malaysia. Tun Abdul Razak memaklumkan bahawa Malaysia tidak lagi berminat untuk mengadakan mesyuarat dengan Indonesia selepas kegagalan di Tokyo dengan alasan, "Indonesia had no intention of changing their position in the slightest". ${ }^{34}$ Sehubungan itu, beliau berharap diluluskan cadangan Jeneral Walter Walker untuk memperluaskan skop operasi merentasi sempadan. Tun Abdul Razak dengan tegas berkata:

'In particular' limit on depth of hot pursuit ambushes must be extended and that the security forces must be free to operate as far as inside Indonesian territory as was necessary. ${ }^{35}$

Namun begitu, Tun Abdul Razak gagal untuk mendapat sokongan apabila Lord Head masih berpendirian bahawa Malaysia mesti 
membawa kes pencerobohan Indonesia itu ke Majlis Keselamatan PBB terlebih dahulu sebelum menjalankan operasi merentasi sempadan.

Malaysia bersetuju untuk membawa kes pencerobohan Indonesia ke Majlis Keselamatan PBB dengan harapan kerajaan British akan membantu menghalang pencerobohan tentera dari negara jiran itu. Walau bagaimanapun, British sekali lagi enggan bertindak sungguhpun tentera Indonesia telah melakukan pencerobohan kali kedua ke atas wilayah Malaysia. Tun Abdul Razak begitu kecewa dan tidak berpuas hati terhadap British. British bukan sahaja enggan meminjamkan pesawat "Hunter" kepada Malaysia, tetapi juga enggan membantu Malaysia menggugurkan risalah ke atas pangkalan tentera Indoensia di Sumatera dalam operasi yang dianggap oleh Malaysia sebagai peaceful. ${ }^{36}$ Perasaan tidak berpuas hati Tun Abdul Razak itu telah dimaklumkan oleh Bottomley kepada Setiauasaha bagi Hal Ehwal Negara-Negara Komanwel sambil menegaskan bahawa:

We seemed to have no conseption of damaging effects on country's morale of failure to take any action to discourage futher landings. What were our promises really worth?...Since Razak on Tunku's behalf clearly considered your misgivings about leaflet droping to be unfounded I wouth as he wished you to reconsider potition urgently. ${ }^{37}$

Tambahnya lagi:

Razak has been much more bellicore than Tunku ever since Security Council meeting if not before. He and C.A.F.S seemed genuinely upset over our reluctance to drop leaflets. If we continue to refuse to help over this I am sure we shall have more difficulty in controlling them later if further landings occur. ${ }^{38}$

Sementara itu, Tun Abdul Razak terus kecewa dengan tindakan Indonesia yang telah mewujudkan pula konflik perkauman di Malaysia melalui siaran radionya dan risalah-risalah anti Malaysia. Beliau menganggap bahawa propaganda itu menjadi punca tercetusnya rusuhan kaum di Singapura pada 22-24 Julai 1964. Pada 8 September 1964, Tun Abdul Razak mengumumkan ejen-ejen Indonesia yang bertanggungjawab mencetuskan rusuhan itu telah ditahan oleh pihak polis Singapura. Pada dasarnya, masalah kegiatan subversif mereka di Malaysia, khususnya di Singapura, telah menyebabkan semakin tegang konflik antara Malaysia dengan Indonesia. ${ }^{39}$

Malaysia bertambah cemas apabila terdapat pendaratan tentera Indonesia di Semenanjung sepanjang bulan Ogos hingga Oktober 1964, di samping pertambahan bilangan tentera Indonesia di perbatasan 
wilayah Borneo dan Sumatera. Susulan itu, Tunku Abdul Rahman telah mengarahkan Tun Abdul Razak selaku Menteri Pertahanan berunding dengan Perdana Menteri British, Harold Wilson di London pada pertengahan bulan November 1964. Rundingan itu adalah untuk mendesak kerajaan British agar mengatur strategi tindak balas yang lebih berkesan terhadap pencerobohan Indonesia. ${ }^{40}$ Pada pertemuan 16 November 1964, Tun Abdul Razak diberi jaminan oleh Harold Wilson bahawa kerajaan British tetap bersama Malaysia menentang pencerobohan Indonesia. Beliau juga bersetuju dengan Harold Wilson bahawa dalam usaha untuk mengekalkan sokongan politik antarabangsa terhadap tindakan Malaysia, masalah pencerobohan itu harus dibawa dengan seberapa segera ke Majlis Keselamatan PBB. ${ }^{41}$

Pada keesokan harinya, Tun Abdul Razak telah mengadakan mesyuarat dengan J.R.A. Bottomley, Setiausaha Negara bagi Hal Ehwal Komanwel. ${ }^{42}$ Mesyuarat ini membincangkan tentang bantuan pertahanan untuk Malaysia dan usaha damai Malaysia Indonesia. Dari segi pertahanan, Tun Abdul Razak memohon sumbangan daripada kerajaan British untuk memperbesar dan memperlengkapkan angkatan tentera Malaysia. Beliau juga meminta kerajaan British menyerahkan kapal frigate dan minesweepers untuk kegunaan angkatan laut Malaysia. Bottomley memberi jaminan bahawa kerajaan British pimpinan parti Buruh akan mempertahankan Malaysia daripada ancaman Indonesia. Tun Abdul Razak sekali lagi diingatkan untuk terlebih dahulu membawa kes itu ke pengetahuan Majlis Keselamatan PBB.

Sementara usaha damai pula, Tun Abdul Razak menjelaskan bahawa Malaysia tidak keberatan untuk mengadakan pertemuan dengan Indonesia jika negara itu memberhentikan dasar agresifnya terhadap Malaysia. Beliau percaya Indonesia tidak ikhlas, sebaliknya cuba menggunakan pertemuan itu untuk memburukkan imej Malaysia yang kononnya boneka British. Bagi Setiausaha Negara Pertahanan, Lord Walston pula memberi jaminan sekiranya kerajaan British dihubungi oleh Indonesia, beliau akan meminta mereka berunding secara langsung dengan kerajaan Malaysia. ${ }^{43}$

Pada 18 Januari 1965, Lord Head telah mengadakan pertemuan dengan Tun Abdul Razak selaku Menteri Pertahanan untuk memaklumkan keputusan mesyuarat ketua-ketua Turus dalam mengatur strategi jika berlaku serangan daripada pihak Indonesia. ${ }^{44}$ Tun Abdul Razak akur dengan keputusan untuk mengatur strategi serangan balas terhadap pangkalan-pangkalan kecil tentera Indonesia di Riau dan beberapa buah pulau yang berdekatan dengan Sumatera, sekiranya Indonesia melancarkan serangan besar-besaran ke atas Sarawak dan Semenanjung Malaysia. Akan tetapi beliau mencadangkan 
agar operasi menyerang pangkalan-pangkalan kecil Indonesia di Riau dan Sumatera dilakukan oleh pasukan Komando Malaysia. Tun Abdul Razak juga dimaklumkan bahawa Britain, New Zealand dan Australia telah bersetuju untuk menghantar pasukan tentera tambahan ke Sabah dan Sarawak bagi mempertahankan wilayah tersebut daripada kemungkinan diceroboh oleh Indonesia. ${ }^{45}$

Selain rundingan dengan pihak British, Tunku Abdul Rahman turut mengarahkan Tun Abdul Razak untuk mendapatkan sokongan dari negara-negara Afrika. Langkah ini diambil berikutan dengan tindakan Indonesia yang telah melancarkan kempen anti Malaysia dalam Persidangan Negara-negara Berkecuali (NAM) di Kaherah pada 5-11 Oktober 1964. ${ }^{46}$ Maka sepanjang bulan November pula, Tun Abdul Razak dan rombongannya telah mengunjungi beberapa buah negara Afrika, termasuklah Mesir, Algeria, Moroko dan Tunisia. Tun Abdul Razak berjaya mendapatkan sokongan dari negara-negara tersebut dan mereka bersedia untuk mengadakan hubungan diplomatik dengan Malaysia. Beliau turut menerangkan keadaan sebenarnya tentang pencerobohan Indonesia terhadap Malaysia. ${ }^{47}$ Sementara itu, sebagai tindak balas lawatan Tun Abdul Razak ke benua Afrika, Indonesia telah menghantar satu rombongan yang diketuai oleh Ali Sastroamidjojo ke Timur Tengah untuk meyakinkan negara-negara itu terhadap pendiriannya menentang Malaysia. Namun, Tun Abdul Razak sekali lagi melawat benua Afrika pada bulan Mac 1965. Beliau bukan sahaja mendapat sokongan dari negara-negara tersebut, tetapi juga berjaya mendapat tempat untuk Malaysia dalam Persidangan Kemuncak Afro-Asia di Algeria pada bulan Jun 1965. Semenjak itu, usaha Indonesia mengecam Malaysia semakin lama semakin kurang mendapat sokongan dari negara-negara Afro-Asia. ${ }^{48}$

Pada dasarnya, antara lain tercetusnya konflik di atas dapat dikaitkan dengan perbezaan personaliti pemimpin tertinggi Malaysia dengan Indonesia. Tunku Abdul Rahman, mahupun Tun Abdul Razak amat berbeza dari segi latar belakang dan perwatakan yang membentuk wawasan politik masing-masing di peringkat nasional dan antarabangsa. Selain itu, Sukarno seorang pemidato yang hebat dan bersifat lebih dinamik berbanding dengan Tunku Abdul Rahman ataupun Tun Abdul Razak. Justeru itu, tidak keterlaluan jika dikatakan sebahagian daripada ketegangan ini juga disebabkan pertembungan personaliti (clash of personalities) antara pemimpin Indonesia dengan Malaysia yang mempunyai pandangan dunia yang berbeza. ${ }^{49}$

Walau bagaimanapun, menjelang pertengahan kedua tahun 1965, terdapat dua peristiwa yang memberi kesan besar dalam hubungan Malaysia-Indonesia iaitu penyingkiran Singapura dari Persekutuan 
Malaysia pada 9 Ogos 1965 dan di Indonesia pula berlaku perebutan kuasa pada 30 September 1965 (dikenali juga sebagai Peristiwa GESTAPU). Secara ringkasnya, usaha memulihkan semula hubungan Malaysia-Indonesia bermula selepas penyerahan kuasa daripada Soekarno kepada Jeneral Suharto dan perlantikan Adam Malik menggantikan Dr. Subandrio sebagai Menteri Luar Indonesia. Pada 4 April 1966, Adam Malik mengatakan beliau ingin melihat konfrontasi ditamatkan secepat mungkin. Susulan itu, suatu pertemuan sulit telah berlangsung antara Ghazali Shafie, Setiausaha Tetap Kementerian Luar Malaysia, dengan Major-Jeneral Ali Moertopo; kemudian disusuli pula rundingan Ghazali Shafie dengan Adam Malik. Rundingan Adam Malik dengan Ghazali Shafie telah membawa kepada pertemuan antara Tun Abdul Razak dengan Adam Malik pada 29 Mei 1966. ${ }^{50}$

Pada 29 Mei 1966, Tun Abdul Razak mengetuai perwakilan Malaysia untuk mengadakan rundingan dengan Adam Malik yang mengetuai rombongan Indonesia di Bangkok. Selepas berunding selama tiga hari, Tun Abdul Razak-Adam Malik telah mengambil keputusan untuk menamatkan permusuhan dan memulihkan semula hubungan diplomatik Malaysia dengan Indonesia. Kedua-dua mereka turut bersetuju untuk mengadakan tinjauan semula terhadap pendirian penduduk Sabah dan Sarawak dalam Persekutuan Malaysia. ${ }^{51}$ Persidangan di Bangkok bukan sahaja memulihkan hubungan Malaysia-Indonesia, tetapi juga telah mencetuskan idea baru dalam usaha menwujudkan pertubuhan serantau yang lebih besar. Tun Abdul Razak-Adam Malik telah mengumumkan satu langkah baru untuk mengadakan kerjasama serantau di antara Malaysia, Indonesia, Filipina dan Thailand. Persidangan Bangkok ini boleh dikatakan menjadi batu asas kepada penubuhan ASEAN pada tahun berikutnya. ${ }^{52}$

Pada 11 Ogos 1966, Tun Abdul Razak ke Jakarta untuk menandatangani perjanjian dengan Adam Malik bagi memulihkan semula hubungan Malaysia-Indonesia. ${ }^{53}$ Semasa ucapan, Tun Abdul Razak berharap "perjanjian persahabatan yang telah ditandatangani pada 17 April 1959 dapat dihidupkan semula dan dapat dijalankan dengan licin dan sempurna." 54 Antara lain perjanjian ini memperakukan keputusan rundingan mereka di Bangkok iaitu menamatkan konfrontasi dan memulihkan semula hubungan diplomatik Malaysia-Indonesia. Tun Abdul Razak juga berjanji bahawa pilihan raya bebas akan diadakan di Sabah dan Sarawak pada tahun 1967. Pilihan raya ini adalah untuk menentukan pendirian masingmasing dalam Persekutuan Malaysia. ${ }^{55}$ Sementara itu, Tun Abdul Razak turut mengumumkan bahawa tentera British akan diundurkan dengan seberapa segera dari kawasan sempadan kedua-dua negara. Jeneral 
Suharto pula mengumumkan bahawa tentera dan sukarelawan Indonesia akan diundurkan dari wilayah Sabah dan Sarawak. ${ }^{56}$ Dengan termeterainya perjanjian ini, berakhirlah secara rasmi konfrontasi Malaysia-Indonesia yang berlangsung selama dua tahun sembilan bulan. Justeru itu, bermulalah era baru dalam hubungan Malaysia Indonesia:

Perjanjian Persetujuan Bangkok yang telah ditandatangani di Jakarta itu adalah merupakan satu kemenangan bagi kedua-dua belah pihak, iaitu kemenangan persaudaraan dan kemenangan semangat muhibah. Tarikh 11 Ogos akan menjadi suatu tarikh yang bersejarah dalam sejarah Indonesia dan Malaysia. Pemulihan hubungan baik menjamin kerjasama yang erat dalam segala lapangan antara Malaysia dan Indonesia, yang kita akan jalankan seberapa baik, apa lagi, dalam bidang bahasa dan pelajaran. Saya yakin Indonesia akan memainkan peranan yang utama dalam menjamin keamanan, kemakmuran dan keteguhan politik di Tenggara Asia ini. ${ }^{57}$

Menyentuh tentang pemulihan hubungan Malaysia-Indonesia, di Indonesia pelbagai pihak seperti Kesatuan Aksi Mahasiswa Indonesia (KAMI), Kesatuan Aksi Pemuda dan Pelajar Indonesia (KAPPI) dan parti-parti politik, kecuali Parti Nasional Indonesia (PNI) menyambut baik pemulihan tersebut. Mereka melaung-laungkan slogan seperti "Hidup Malaysia" dan "Hidup Tun Razak". ${ }^{58}$

Bagi mengukuhkan lagi hubungan, Adam Malik telah mengetuai satu rombongan yang terdiri daripada 45 orang ke Malaysia pada 12 Ogos 1966. ${ }^{59}$ Pada tarikh yang sama, Tun Abdul Razak dan rombongannya pulang ke Malaysia dengan diberi sambutan "Hero's Welcome" di Kuala Lumpur. Kerajaan negeri Selangor telah memberi cuti pada hari tersebut dan mengarahkan kakitangannya berada di Lapangan Terbang Subang untuk menyambut kepulangan Tun Abdul Razak. Sekitar 15 ribu orang berada di Subang untuk menyambut Tun Abdul Razak dan rombongannya. ${ }^{60}$

Pada 29 September 1966, Indonesia dengan rasminya menyertai semula PBB dan juga agensi-agensi PBB. Pada ketika itu, Malaysia amat mengalu-alukan penyertaan semula Indonesia di PBB. Semasa berada di PBB, Tun Abdul Razak berkata:

On behalf of my country, I wish to take this opportunity of extending a formal welcome back to this organization of the delegation of Indonesia whose wise counsel in our debates has always been availabe to this organization and which again will be available with fresh vigour and a new earnesstness. ${ }^{6}$ 
Ketokohan Tun Abdul Razak terserlah apabila beliau antara pemimpin yang terlibat dalam menamatkan konfrontasi secara rundingan dan hikmah. Perjanjian yang ditemeterai itu telah berjaya memulihkan semula hubungan di antara Republik Indonesia dengan Malaysia. Bagi Tun Abdul Razak, berakhirnya konfontasi itu menandakan kembalinya bertaut satu rumpun bangsa yang terpisah seperti kata pepatah, "carik-carik bulu ayam akhirnya bercantum juga" ${ }^{62}$

Gambar 2

Tun Razak menandatangani persetujuan damai dengan Adam Malik, Menteri Luar Negeri Indonesia di Jakarta pada 11 Ogos 1966.

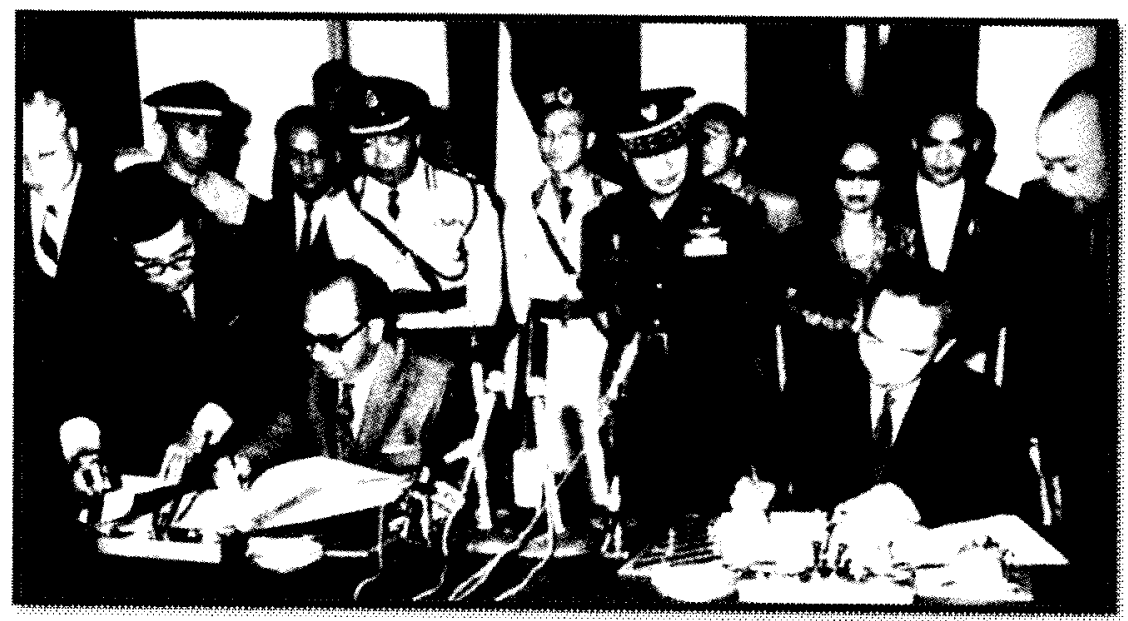

Sumber: Arkib Negara Malaysia, Kuala Lumpur.

\section{Kesimpulan}

Tun Abdul Razak merupakan antara tokoh yang turut memainkan peranan penting dalam membina hubungan Malaysia-Indonesia semasa peringkat awal kemerdekaan. Beliau telah memulakannya dengan mengadakan lawatan rasmi ke Indonesia sebagai tanda hubungan rasmi dijalinkan selepas berakhirnya era penjajahan. Namun begitu, konfrontasi Malaysia-Indonesia telah merenggangkan hubungan di antara kedua-dua negara tersebut. Selaku Timbalan Perdana Menteri, Tun Abdul Razak turut terlibat secara langsung dalam beberapa rundingan untuk meleraikan kemelut itu secara diplomasi dan bijaksana. Hanya apabila berlaku perubahan pucuk 
kepimpinan kerajaan Indonesia dari Soekarno kepada Jeneral Suharto dan pelantikan Adam Malik menggantikan Dr. Subandrio sebagai Menteri Luar Indonesia barulah langkah perdamaian lebih mudah dilaksanakan di antara kedua-dua negara. Seterusnya, Tun Abdul Razak mengambil langkah proaktif untuk mengukuhkan semula hubungan dengan memulakan kunjungannya ke Jakarta. Jelaslah sebagai negara yang berjiran, faktor pertalian sejarah, rumpun bangsa dan kebudayaan telah merapatkan semula hubungan kedua-dua negara.

\section{Nota}

1 Razak mengakui dirinya berketurunan Bugis yang berasal dari Kampung Makasar, Sulawesi. Lihat, "Ucapan Perdana Menteri Tun Abdul Razak di Upacara Menerima Hadiah Kapal Layar "Putera Mengkasar" dari Rakyat Sulawesi di Pelabuhan Kelang, Selangor pada 1 September 1975," Ucapan-ucapan Tun Haji Abdul Razak Bin Hussein 1975, Arkib Negara Malaysia dan Jabatan Perdana Menteri, Kuala Lumpur, 1977, hlm. 158.

2 Ibrahim Mahmood, Sejarah Perjuangan Bangsa Melayu: Suatu Penyingkapan kembali Bangsa Melayu Menuju Kemerdekaan, Kuala Lumpur: Penerbitan Pustaka Antara, 1981, hlm. 617.

3 Lihat, Kunaseelan Muniandy, Hubungan Malaysia-Indonesia 1957-1970, Kuala Lumpur: Dewan Bahasa dan Pustaka,1996, hlm. 61.

$4 \quad$ Antara Daily News Bulletin, 14 November 1958.

5 Sebagai contoh, isu Irian Barat, pemberontakan PRRI (Pemerintah Revolusioner Republik Indonesia), pencerobohan kawasan pengairan dan pertikaian sempadan negara. Untuk keterangan lanjut sila lihat, Mohd Sohaimi Esa, "Tun Razak dalam Hubungan Persekutuan Tanah Melayu-Indonesia Sebelum Penubuhan Malaysia", Seminar MALINDO Nusantara 1, Anjuran UKM dan Universiti Andalas, Bukit Tinggi, 2009; Ruhanas Harun, "Kerjasama dan Konflik dalam Hubungan Malaysia-Indonesia," Malaysia's Foreign Relations: Issues and Challenges. Edited by Ruhanas Harun, Kuala Lumpur: University of Malaya Press, 2006, hlm. 52-53.

$6 \quad$ Malaya/Indonesia Relations, $31^{\text {st }}$ August $1957-15^{\text {th }}$ September 1963, Kuala Lumpur: Jabatan Penerangan, 1963, hlm. 2.

$7 \quad$ Antara Daily News Bulletin, 21 November 1958.

8 Antara Daily News Bulletin, 4 Disember 1958; Malaya/Indonesia Relations, $31^{\text {st }}$ August $1957-15^{\text {th }}$ September 1963, hlm. 21-24.

9 J.A.C. Mackie, Confrontations: The Indonesia-Malaysia Dispute, 1963-1966, Kuala Lumpur: Oxford University Press, 1974, hlm. 29.

10 Kunaseelan Muniandy, Hubungan Malaysia-Indonesia, hlm. 94.

11 Arnold Brackman, Southeast Asia's Second Front: The Power Struggle in the Malay Archipelago, Frederick A. Praeger, New York, 1966, hlm. 149. Untuk ulasan lanjut perkembangan konfrontasi Malaysia-Indonesia 
sebelum penubuhan Malaysia sila lihat, Kunaseelan a/1 Muniady, Hubungan Malaysia Indonesia, hlm. 162-184; Nik Anuar Nik Mahmud, Konfrontasi Malaysia Indonesia, hlm. 75-83 dan 108-120.

12 Straits Times, 6 September 1963

13 Lihat, Straits Times, 16 September 1963

14 "Address by the Deputy Prime Minister to Council on World Tension Conference Delegates on $28^{\text {th }}$ February, 1964", dalam Ucapan-Ucapan Tun Haji Abdul Razak bin Hussein 1964, hlm. 44.

15 "Ucapan Timbalan Perdana Menteri Dalam Siri Ceramah oleh MenteriMenteri Melalui Suara Malaysia pada 14hb Disember, 1963," dalam Ucapan-Ucapan Tun Haji Abdul Razak bin Hussein 1963, hlm. 208.

16 Ibid., hlm. 209.

17 Ruhanas Harun, "Kerjasama dan Konflik", hlm. 54.

18 PREM 11/4905, Telegram dari Kuala Lumpur ke Pejabat Luar, 24 Disember 1963.

19 "Ucapan Timbalan Perdana Menteri dan Menteri Pertahanan Berkenaan dengan Peristiwa yang Berlaku di Daerah Kalabakan, Sabah di Dewan Rakyat pada 3 Januari 1964", dalam Ucapan-ucapan Tun Haji Abdul Razak bin Hussein, 1964, hlm. 1-5.

20 Robert Kennedy, Peguam Negara Amerika Syarikat telah bertemu dengan beberapa orang pemimpin di rantau Asia Tenggara, khususnya Malaysia dan Indonesia untuk meleraikan konflik konfrontasi tersebut. Untuk maklumat lanjut sila lihat, Nik Anuar Nik Mahmud, Konfrontasi Malaysia-Indonesia, hlm. 134-138; Abdullah Ahmad, Tunku Abdul Rahman dan Dasar Luar Malaysia, 1963-1970, Kuala Lumpur: Berita Publishing, 1987; A.G. Mezerik,ed., Malaysia-Indonesia Conflict, hlm. 44-45.

21 Lihat, Marvin C. Ott, "The Sources and Content of Malaysian Foreign Policy", Asian Survey, Jil. 9, No. 5, Mac 1972, hlm. 297.

22 Lihat, "Joint Communique of the Bangkok Ministrial Meeting, 11 February 1964", dalam A.G. Mezerik, ed., Malaysia-Indonesia Conflict, hlm. 114.

23 Lihat, Perkara 7 dalam Joint Communique of the Bangkok Ministrial Meeting.

24 Antara Weekly Review, 8 Februari 1964.

25 Straits Times, 12 Februari 1964.

26 PREM 11/4905, Surat Tun Abdul Razak (Kuala Lumpur) kepada Pejabat Perhubungan Komanwel, 21 Februari 1964.

27 Ulasan lanjut sila lihat, Nik Anuar Nik Mahmud, Konfrontasi Malaysia Indonesia, hlm. 141-142.

28 Malay Mail, 3 Mac 1964; Asian Recorder, 1-7 April 1964, hlm. 5756.

29 Lihat, Asian Recorder, 1-7 April, 1964, hlm. 5756; Starits Times, 6 Mac 1964.

30 PREM 11/4907, Surat Perdana Menteri British (Pejabat Perhubungan Komanwel) kepada Tunku Abdul Rahman, 5 Mac 1964.

31 Untuk maklumat lanjut sila lihat, Nik Anuar Nik Mahmud, Konfrontasi Malaysia-Indonesia, hlm. 146 
32 Malay Mail, 14 Jun 1964; Marvin C. Ott, "The Sources and Content of Malaysian Foreign Policy," hlm. 322; Frances L. Sterner, "Malaysia's First Year", Asia Survey, Jil. 5, No. 2, Februari 1965, hlm. 115.

33 Ulasan lanjut sila lihat, Nik Anuar Nik Mahmud, Konfrontasi MalaysiaIndonesia, hIm. 147-150; Kunaseelan a/l Muniandy, Hubungan MalaysiaIndonesia, hIm. 212-231; A.G. Mezerik, ed., Malaysia-Indonesia Conflict, hIm. 46; Straits Times, 22 Jun 1964.

34 PREM 11/4907, Telegram dari Kuala Lumpur ke Pejabat Perhubungan Komanwel, 24 Jun 1964.

35 Ibid

36 Nik Anuar Nik Mahmud, Konfrontasi Malaysia Indonesia, hlm. 169.

37 FO 371/176480, Telegram dari Kuala Lumpur ke Pejabat Perhubungan Komanwel, 30 Oktober 1964.

38 Ibid.

39 Asian Recorder, 19-25 Ogos 1964, hlm. 6000; Keesing's Contemporary Archives, Longman Group, London, 20-27 Februari 1965, hIm. 20594; Kunaseelan a/1 Muniandy, Hubungan Malaysia Indonesia, hlm. 205.

$40 \quad$ Nik Anuar Nik Mahmud, Konfrontasi Malaysia Indonesia, hlm. 174.

${ }^{41}$ FO 371/176485, Statement by Prime Minister, Record of Meeting held in the Commonwealth Relations Office on Tuesday, 17 th November 1964.

42. Antara yang hadir dalam rundingan ini termasuklah Denis Headley, Setiausaha Negara bagi Pertahanan, Lord Walston, Setiausaha Bawah Parlimen bagi Hal Ehwal Luar dan pegawai-pegawai kanan British. Selain Tun Abdul Razak, wakil Malaysia yang turut hadir ialah Tunku Yaakob, Pesuruhjaya Tinggi Malaysia di United Kingdom, Hussein Mohamed Osman, Timbalan Pesuruhjaya Tinggi dan Abdullah Ahmad. Lihat, Nik Anuar Nik Mahmud, Konfrontasi Malaysia Indonesia, hlm. 175.

43 Ibid., hlm. 175.

$44 \quad$ Mereka yang hadir dalam mesyuarat ini termasuklah Admiral Sir Varl Begg, Wade, Pesuruhjaya Tinggi New Zealand, Critchley, Pesuruhjaya Tinggi Australia dan Jeneral Tengku Osman Jiwa, Ketua Turus Angkatan Bersenjata Malaysia. Lihat, FO 371/181526, Telegram dari Kuala Lumpur ke Pejabat Perhubungan Komanwel, 19 Januari 1965.

45 Untuk ulasan lanjut sila lihat, Nik Anuar Nik Mahmud, Konfrontasi Malaysia Indonesia, hlm. 180-182.

46 Persidangan tersebut diadakan pada 5-11 Oktober 1964 dan dihadiri oleh ketua-ketua kerajaan dari 47 buah negara. Lihat, Mezerik, MalaysiaIndonesia Conflict, hIm. 93.

47 Berita Harian, 28 November 1964; Abdullah Ahmad, Tunku Abdul Rahman dan Dasar Luar Malaysia, hlm. 73.

48 Berita Harian, 29 Mac, 2 dan 3 April 1965; Asian Recorder, 28 Mei - 3 Jun 1965, hlm. 6477.

49 Ruhanas Harun, "Kerjasama dan Konflik", hlm. 56-57.

50 Kunaseelan, Hubungan Malaysia-Indonesia, hlm. 226-230. 
51 Keesing's Contemporary Archives, Longman Group, London, 9-16 Julai 1966, hlm. 21493 dan Weinstein, Indonesia Abandons Confrontation, hlm. 55.

52 "Address by the Deputy Prime Minister to Council of Foreign and International Affairs of Thailand in Bangkok on $1^{\text {st }}$ August, 1966," dalam Ucapan-ucapan Tun Haji Abdul Razak bin Hussein, 1966, hlm. 198-206.

53. Tun Abdul Razak dan Adam Malik menandatangani perjanjian itu di hadapan Jeneral Suharto. Lihat, Foreign Affairs Malaysia, Kementerian Luar Negeri, Kuala Lumpur, Jil. 1, No. 3, 1966, hlm. 22.

54 "Ucapan Timbalan Perdana Menteri di Upacara Menandatangani Perjanjian Perdamaian Indonesia dan Malaysia pada 11 Ogos, 1966," dalam Ucapan-ucapan Tun Haii Abdul Razak bin Hussein, 1966, hlm. 217.

55 Lihat, Agreement to Normalize Relations Between The Repbulic of Indonesia and Malaysia, Foreign Affairs Malaysia, Kementerian Luar Negeri, Kuala Lumpur, Jil. 1, No. 3, 1963, hlm. 1-2.

56 Straits Times, 12 dan 14 Ogos 1966.

${ }^{57}$ "Ucapan Timbalan Perdana Menteri di Majlis Memperingati Hari Kemerdekaan Indonesia, dan Perdamaian Indonesia-Malaysia, di Dewan Bahasa dan Pustaka, Kuala Lumpur pada 17 Ogos, 1966", dalam Ucapan-ucapan Tun Haji Abdul Razak bin Hussein, 1966, hlm. 217.

58 Straits Times, 12-13 Ogos 1966.

59 Keesing's Contemporary Archives, Longman Group, London, 20-27 Ogos 1966, hlm. 21576 dan juga Straits Times, 13 Ogos 1966.

60 Straits Times, 12 Ogos 1966.

61 Djakarta Times, 26 September 1966.

62 Lihat, "Speech by The Deputy Prime Minister at the Debate Resumed on the Motion of the 'Perjanjian Perdamaian dengan Indonesia' at Dewan Rakyat on 26 $6^{\text {th }}$ August, 1966," dalam Ucapan-ucapan Tun Haji Abdul Razak bin Hussein, 1966, hlm. 250-255. 